\title{
Se tegnene på omsorgssvikt!
}

Sykepleiere på legevakt vil sannsynligvis oppleve å mistenke omsorgssvikt hos barn. De trenger kunnskap for å gjenkjenne tegn og symptomer .

\section{Forfattere}

\section{Ida R. Thorvaldsen}

Sykepleier

\section{Jörg W. Kirchhoff}

Førsteamanuensis

Høgskolen i Østfold

\section{Nøkkelord}

Omsorgssvikt Legevakt Barn

Sykepleien 2017 105(1)(50-53)

DOI: https://doi.org/10.4220/Sykepleiens.2017.59740

HOVEDBUDSKAP

Det er et gap mellom antall barn som er utsatt for omsorgssvikt, og antall barn som mottar tiltak fra barnevernet. Å styrke kunnskapen blant sykepleiere på legevakt kan være et viktig bidrag til å redusere noe av gapet. 
Som sykepleiere yter vi ikke bare helsehjelp, men vi får i mange tilfeller også kjennskap til årsaken som utløser behovet for helsehjelp. For eksempel kan et uheldig sammenstøt på fotballbanen resultere i en brukket ankel, eller skaden kan være forbundet med ulovlig aktivitet, som kjøring i beruset tilstand. Samtidig pålegger taushetsplikten oss å avstå fra å videreformidle disse opplysningene. Det finnes imidlertid unntak. Ett av unntakene er når vi mistenker at barn kan være utsatt for omsorgssvikt. «[N]år det er grunn til å tro at et barn blir mishandlet i hjemmet eller det foreligger andre former for alvorlig omsorgssvikt ...» pålegges vi, og annet helsepersonell, å varsle barnevernet (1).

Samtidig er det kjent at selv om helsepersonell kan oppleve mistanke om omsorgssvikt, medfører det ikke nødvendigvis at mistanken meldes videre. En studie i Australia avdekket blant annet at selv om 43 prosent av sykepleierne hadde hatt mistanke eller var overbevist om at barn var utsatt for omsorgssvikt, valgte bare 21 prosent å rapportere saken videre (2).

\section{Studie i Østfold}

Det finnes lite kunnskap om hvordan sykepleiere i Norge håndterer en slik mistanke. I denne artikkelen ønsker vi å presentere funn fra en studie blant sykepleiere på to legevakter i Østfold. Studien sier noe om hvilke faktorer som påvirker hvorvidt sykepleierne varsler barnevernet eller ikke når de mistenker at barn er utsatt for omsorgssvikt.

\section{Mørketall}


Det er svært usikkert hvor ofte barn utsettes for omsorgssvikt i Norge. Offentlig statistikk har for eksempel registrert at cirka fire prosent av norske barn årlig mottar tiltak fra barnevernet (3). En nasjonal undersøkelse fant derimot at 8,5 prosent av 16- og 17åringer hadde opplevd en eller annen form for omsorgssvikt under oppveksten (4). Forskjellen mellom offentlig statistikk og spesifikke studier indikerer at det er mørketall.

Det man derimot vet, er at det er viktig å få avdekket omsorgssvikt for å forebygge fremtidige skader. For eksempel fant MacMillan og medarbeidere at personer som hadde opplevd omsorgssvikt i barndommen, hadde større sannsynlighet for å få angstlidelser, depresjoner og antisosial atferd i voksen alder (5). I tillegg viser Nagler at jenter utsatt for omsorgssvikt, har høyere risiko for å utvikle unormalt sinne, depresjoner og posttraumatiske stresslidelser. Gutter utvikler gjerne depresjoner og aggressiv oppførsel (6). Av den grunn er meldeplikten et viktig forebyggende tiltak.

\section{Hva påvirker varsling?}

Internasjonale studier viser til tre hovedårsaker for å forklare varierende varsling blant helsepersonell når de mistenker omsorgssvikt: varierende grad av kunnskap, varierende grad av tiltro til barnevernet og frykt for konsekvensene ved en varsling.

\section{Kunnskap}


Begrenset kunnskap i å gjenkjenne tegn og symptomer på omsorgssvikt har vist seg å være en barriere for innrapportering. Denne manglende kunnskapen har ført til en underrapporteringskultur blant sykepleiere $(7,8)$. Sykepleierne var usikre på hva de skulle se etter, og dermed overså de barnas behov for hjelp. Også når sykepleierne hadde gjort mistenkelige funn, men ikke forsto hva funnene betydde, underrapporterte de. Det var større sannsynlighet for at sykepleiere som opplevde at de hadde tilstrekkelig kunnskap om temaet, varslet barnevernet (9).

Et annet aspekt i denne sammenhengen er kunnskap om hvordan man skal håndtere en eventuell mistanke om omsorgssvikt hos barn. En studie i Nord-Irland viser blant annet at 77 prosent av sykepleierne følte seg usikre på prosedyrene for å rapportere til barnevernet, eller på hvem de skulle melde fra til (10). Når ansatte mangler ferdigheter i å ta tak i situasjonen, fører det til at de ikke varsler barnevernet (11).

\section{Tiltro til barnevernet}

Fraser og medarbeidere fant at når sykepleierne hadde negative holdninger til barnevernet, var det større sannsynlighet for at de lot være å melde fra ved mistanke om omsorgssvikt (2). En av hovedgrunnene til manglende tiltro var at de var usikre på om det å melde fra, ville være til fordel for barnefamilien. I tillegg hadde noen erfaringer med at varslinger ikke var blitt håndtert på en tilfredsstillende måte av barnevernet (10). Liten tro på barnevernets arbeid fører dermed til at terskelen for å rapportere til barnevernet blir høyere, og at sykepleiere nøler med å melde fra (7).

\section{Frykter konsekvenser}


Til slutt vil frykten for konsekvensene av å varsle om omsorgssvikt påvirke graden av rapportering. Til konsekvensene hører blant annet frykt for å såre familien (11), frykt for at familien ikke vil kontakte helsevesenet ved en senere anledning (7), og frykt for at det rettes formelle klager mot helsevesenet, som resulterer i eventuelle rettssaker (10). Særlig i små samfunn kviet sykepleiere seg for å rapportere. Årsaken var at de var redde for at det skulle bli oppdaget hvem som hadde meldt fra, og at det skulle få konsekvenser for dem selv (7).

\section{Spørreundersøkelse}

Legevakten tilhører førstelinjetjenesten, der pasienter søker øyeblikkelig hjelp ved relativt enkle skader eller sykdom (13). Dermed utgjør legevakten en arena der sykepleiere ofte møter barn og deres familie. Det er stor sannsynlighet for at sykepleierne kommer i situasjoner der de kan få mistanke om omsorgssvikt.

Vi ønsket å studere hvordan sykepleiere håndterer mistanke om omsorgssvikt blant barn og valgte å gjennomføre en spørreundersøkelse (12). I løpet av våren 2016 distribuerte vi et spørreskjema blant 70 ansatte ved to legevakter i Østfold. 24 sykepleiere svarte på undersøkelsen, og det gir en svarprosent på 34.

Skjemaet innledet med å informere de ansatte om formålet med studien, og om at svarene blir behandlet konfidensielt. Skjemaet var tematisert etter spørsmål om bakgrunnsopplysninger, sykepleiernes egen vurdering om kunnskap om omsorgssvikt, hvorvidt de hadde opplevd mistanke om omsorgssvikt ved legevakten og hvordan de håndterte mistanken eller ville ha håndtert en slik mistanke. I tillegg stilte vi spørsmål om hvorvidt kunnskap, tiltro til barnevernet og frykt for konsekvensen av å melde fra til barnevernet hadde betydning for valget de gjorde da de mistenkte omsorgssvikt. 
Vi registrerte de besvarte skjemaene og analyserte svarene ved hjelp av uni- og bivariate analyser i SPSS 23. Valgt signifikansnivå var 5 prosent.

\section{Mistenker omsorgssvikt}

Tabell 1 presenterer sykepleierne som deltok i studien og viser hvor ofte de har hatt mistanke om omsorgssvikt.

Tabell 1. Presentasjon av utvalget $(\mathrm{n}=$ antall svar $)$

\begin{tabular}{rrr}
\hline & Antall (n) & Andel (\%) \\
\hline Kjønn & 23 & 100 \\
Kvinner & 18 & 78 \\
Menn & 5 & 22 \\
Alder & 24 & 100 \\
$<25$ år & 1 & 4 \\
$26-35$ år & 2 & 8 \\
$36-45$ år & 8 & 34 \\
$>45$ år & 13 & 54 \\
55 år & 24 & 100 \\
$>5$ år & 11 & 46 \\
Yrkeserfaring ved legevakt & 13 & 54 \\
Har du opplevd mistanke om & 24 & 100 \\
omsorgssvikt? & & \\
Ja & 18 & 75 \\
Nei & 6 & 25 \\
Hvor ofte har du & 18 & 100 \\
opplevd mistanke om & & 78 \\
omsorgssvikt? & & 11 \\
1-5ganger & 14 & 11 \\
$9-10$ ganger & 2 & \\
Mer enn 10 ganger & 2 &
\end{tabular}


Tabellen viser at mer enn halvparten av sykepleierne, det vil si 18 av 24 sykepleiere, har hatt mistanke om omsorgssvikt på legevakten. Analysen viste videre at sykepleiere med mer enn fem års yrkeserfaring oftere hadde hatt mistanke om omsorgssvikt.

\section{Søker råd fra kollegaer}

I neste omgang ble sykepleierne bedt om svare på hva de gjorde da de hadde fått mistanke om omsorgssvikt hos barn, eller hva de tror de ville ha gjort dersom de befant seg i en slik situasjon.

Tabell 2. Handlingsalternativer ved mistanke om omsorgssvikt $(n=24)$

\begin{tabular}{rrr}
\hline & Antall ( $\mathrm{n})$ & Andel (\%) \\
\hline Søke råd hos kollegaer & 19 & $\mathbf{7 9}$ \\
Varsle vakthavende lege & 19 & 79 \\
Varsle barnevernet & 17 & 71 \\
Snakke med foreldrene & 5 & 21
\end{tabular}

Tabell 2 viser at de fleste valgte eller ville ha valgt å søke råd hos kollegaer eller legen ved legevakten, mens et mindretall ville ha henvendt seg til foreldrene. I tillegg ville de fleste ha varslet barnevernet. Analysen viste ingen signifikante forskjeller i sykepleiernes svar på de ulike handlingsalternativene da vi sammenliknet de som hadde hatt mistanke om omsorgssvikt, og de som ikke hadde vært i en slik situasjon.

Avslutningsvis ble sykepleierne spurt i hvilken grad kunnskap, tiltro til barnevernet og frykt for eventuelle konsekvenser ved å varsle hadde betydning for hvorvidt de varslet eller ville ha varslet barnevernet. Figur 1 viser at et flertall av sykepleierne legger stor betydning i kunnskap og tiltro til barnevernet, mens frykt for konsekvensene ikke hadde noen betydning for majoriteten. 


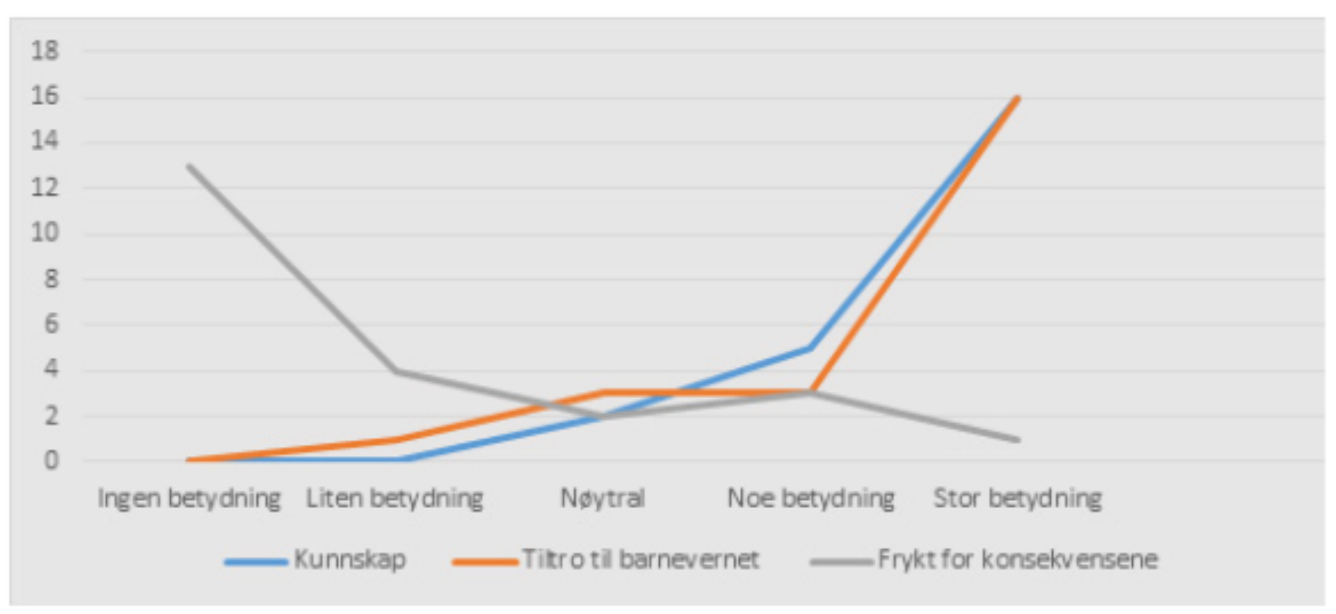

Analysen viste at sykepleiere som tidligere hadde opplevd mistanke om omsorgssvikt, syntes kunnskap var viktigere enn sykepleiere som ikke hadde opplevd mistanke. I tillegg fant vi at sykepleiere som mente de hadde god kunnskap om omsorgssvikt, var mer tilbøyelige til å varsle barnevernet. Sykepleiernes tiltro til barnevernet eller frykt for konsekvenser innvirket ikke på hvorvidt de varslet eller ikke.

Vår studie er for liten i omfang til å kunne trekke bastante konklusjoner på vegne av sykepleiere ved norske legevakter. Samtidig kan funnene våre bidra til å belyse en problemstilling som man dessverre har for lite kunnskap om. Vi håper derfor at studien kan være en pilot for fremtidige studier. I tillegg er det funn i vår studie som det er viktig å få undersøkt nærmere.

\section{Nøkkelrolle}


De fleste, det vil si 18 av 24 sykepleiere (75 prosent) ved legevaktene, svarte at de har vært i situasjoner der de fikk mistanke om omsorgssvikt hos barn. Disse tallene indikerer at sykepleiere på ett eller annet tidspunkt i karrieren blir nødt til å forholde seg til problemstillingen. Sykepleiere vil være blant de første som kan avdekke hvorvidt barn og deres familie trenger bistand ut over den hjelpen de søker på legevakten. Samtidig er det viktig at de har kunnskap om hva som kjennetegner omsorgssvikt, og om hvordan de skal forholde seg når de har avdekket omsorgssvikten.

\section{Behov for kunnskap}

Sykepleierne, og spesielt de som hadde opplevd mistanke om omsorgssvikt, påpekte at kunnskap var viktig. Tidligere studier har vist at kunnskap ikke bare er viktig for å avdekke omsorgssvikten, men også for å øke sannsynligheten for at sykepleiere rapporterer mistanken videre (9). Samtidig er det usikkerhet om hvor mye og hvilken kunnskap som er nødvendig for å videreformidle mistanke og iverksette tiltak. For eksempel var det ingen sammenheng mellom kunnskap og varsling i én studie (14), mens en annen kunne vise til at sykepleiere med spesifikk trening innenfor området oftere rapporterte sine mistanker enn de som ikke hadde slik trening (2). Disse momentene indikerer at det er et behov for målrettet opplæring av sykepleiere til å kunne håndtere situasjoner når de får mistanke om omsorgssvikt.

\section{Varsle barnevernet}

Til tross for at loven pålegger helsepersonell å varsle barnevernet når de mistenker omsorgssvikt, svarte sju av 17 sykepleiere at de ikke varslet eller ikke ville ha varslet barnevernet. Likevel oppga sykepleierne at de hadde tiltro til barnevernet. 
Samtidig svarte sykepleierne som ikke varslet eller ikke ville ha varslet, at de enten ville ha søkt råd hos en kollega eller varslet en lege. Det kan bety at samspillet med kollegaer på legevakten har betydning for hvordan sykepleierne håndterer sin mistanke. Skårderud, Haugsgjerd og Stänicke beskriver blant annet at når man har tanker og følelser det er vanskelig å stå inne for, søker man samspill med andre for å prøve å kvitte seg med disse følelsene, og eventuelt fraskrive seg ansvaret for følelsene (15). Dataene våre er imidlertid ikke tilstrekkelige til å kunne vurdere hvorvidt fagfellesskapet hemmer eller fremmer varsling til barnevernet.

\section{Sykepleiere har ansvar}

Vår lille studie peker på hvilken nøkkelrolle sykepleiere på legevakten har for å avdekke omsorgssvikt hos barn. Som helsepersonell i førstelinjetjenesten er det stor sannsynlighet for at de vil oppleve situasjoner der de mistenker omsorgssvikt hos barn.

Et viktig skritt på veien for å ivareta varslingsansvaret er å styrke kompetansen, både når det gjelder å kjenne igjen tegn på omsorgssvikt og håndtere lovens krav om varsling.

Da det er lite norsk forskning på dette området, håper vi at artikkelen vår kan inspirere til videre forskning på temaet, og dermed hjelpe barn og deres familier. Barns helse er en god investering i fremtiden.

\section{Referanser}

1. Lovdata. Lov om helsepersonell m.v. 2. juli 1999; nr. 64. [Helsepersonelloven]. Paragraf 33. Tilgjengelig fra: https://lovdata.no/dokument/NL/lov/1999-07-02-64. (Nedlastet 03.11.2012). 
2. Fraser JA, Mathews B, Walsh CL, Dunne M.

Factors influencing child abuse and neglect

recognition and reporting by nurses: A multivariate

analysis. International Journal of Nursing Studies

2010;47(2):146-53.

3. Statistisk sentralbyrå. Barnevern. 2003-2014.

Tabell: 09050: Gutter og jenter fra 0 til og med 17 år i

hele landet, med alle tiltak i år 2003 og 2014. 2003-

2014. Tilgjengelig fra:

https://www.ssb.no/statistikkbanken/selecttable/hovedtabellHjem.asp?

KortNavnWebbarneverng\&CMSSubjectAreasosiale-

forhold-og-kriminalitet\&checkedtrue. (Nedlastet

06.05.2016).

4. $\quad$ Myhre M, Thoresen S, Hjemdal OC. Vold og

voldtekt i oppveksten. En nasjonal

intervjuundersøkelse av 16- og 17-åringer. Oslo:

Nasjonalt kunnskapssenter om vold og traumatisk

stress. 2015.

5. MacMillan HL, Fleming JE, Streiner DL, Lin

E, Boyle MH, Jamieson E, Duku EK, Walsh CA, Wong MY-Y, Beardslee WR. Child abuse and lifetime psychopathology in a community sample. American Journal of Psychiatry 2001;158:1878-83.

6. Nagler J. Child abuse and neglect. Current Opinion in Pediatrics 2002;14:251-4.

7. Piltz A, Wachtel T. Barriers that inhibit nurses reporting suspected cases of child abuse and neglect.

Australian Journal of Advanced Nursing 2009;26(3):93-100.

8. Sanders T, Cobley C. Identifying nonaccidental injury in children presenting to $A \& E$ departments: an overview of the literature. Accident \& Emergency Nursing 2005;13(2):130-6. 
9. $\quad$ Feng J, Wu Y. Nurses' intention to report child abuse in Taiwan: a test of the theory of planned behavior. Research in Nursing \& Health 2005;28(4):337-47.

10. Lazenbatt A, Freeman R. Recognizing and reporting child physical abuse: a survey of primary healthcare professionals. Journal of Advanced Nursing 2006;56(3):227-36.

11. Glasser S, Chen W. Survey of a pediatric hospital staff regarding cases of suspected child abuse and neglect. Israel Medical Association Journal 2006;8:179-83.

12. Dalland O. Metode og oppgaveskriving. Oslo: Gyldendal Akademisk. 2015.

13. Helsedirektoratet. Dette kan legevakten gjøre for deg. Tilgjengelig fra:

https://helsenorge.no/hjelpetilbud-ikommunen/legevakt\#Dette-kan-legevakten-gjøre-fordeg-. (Nedlastet 11.04.2016).

14. Ben Natan M, Faour C, Naamhah S, Grinberg $\mathrm{K}$, Klein-Kremer A. Factors affecting medical and nursing staff reporting of child abuse. International Nursing Review 2012;59(3):331-7.

15. Skårderud F, Haugsgjerd S, Stänicke E. Psykiatriboken. Sinn - kropp - samfunn. Oslo: Gyldendal Akademisk. 2013. 